\title{
Against Relativism. The Importance of Truth in the Ethics of St. John Paul II
}

\begin{abstract}
The main aim of the paper is the analysis and critique of axiological relativism, typical of contemporary Western culture. Its supporters deny the objective status of moral norms and values. Axiological relativism leads to moral indifference based on blurring the difference between good and evil, and negating the belief that human action may be morally better or worse. I present the anti-relativistic position of St. John Paul II, particularly in relation to the truth, understood as a cognitive and moral value. According to the Pope, a civilization based on the belief of the relative nature of good and evil leads to widespread hypocrisy and is destined to a slow decline.
\end{abstract}

Keywords

Axiological relativism - Ethics - Truth - Moral good - St. John Paul II.

\section{The axiological relativism and its negative consequences}

Currently, a very ,fashionable way of ordering the world is relativism, especially in its axiological version. Axiological relativism is developing relationships based on the relativity of truth, and above all, the truth about the good. There are many varieties of relativism: cognitive, linguistic, cultural, or axiological. In general, any doctrine which holds that existence of something (a value, the status quo) depends on something else, something which exists only in relation to something else, can be considered as relativist. Thus, there is no absolute truth, one which 
is independent of man, place and time. The values are determined and defined by culture, society, or the individual ${ }^{1}$.

In its extreme form, cognitive relativism claims that all beliefs: individual and collective are real (i.e. cognitively equivalent). In addition, if a judgment is true, it is only true ,for someone' or ,due to someone. There are no sentences, which would be true regardless of certain criteria ${ }^{2}$.

Language relativism assumes, on the other hand, that our understanding and description of the world are determined by the structure of our language. Therefore, it is the diversity of languages that forms different patterns of thinking, exploring the world and evaluating people's attitudes. The relativistic theory of language serves cultural relativists as the basis for their argumentation. They ascribe different cultures the status of certain realities sui generis, with a unique and incomparable structure. Thus, all cultures are equal, and promoting one of them is discrimination - both racial and ethnic. Axiological equality of cultures means that every ethos, style and pattern of life propagated by a given culture is equivalent to the other ${ }^{3}$.

Let us discuss the main subject of our consideration - the axiological relativism. Its supporters claim that there are no objective standards of norms and values. Let us recall that the word ,relativism' is derived from the Latin word, relativus', which indicates relations, and the relativity of truth about the good. What is morally good for one person, is not necessarily so - for the other. What is morally wrong for one person, can be morally neutral for others. Thus, in their ontological status, good and evil are dependent on human notions, as well as historical and cultural conditions ${ }^{4}$. It follows that all moral judgements are equally valid. It should also be added that axiological relativism is not only about the very variety of views on values and norms. The theory would then be acceptable as a meta-system concept, as part of a broadly understood research concept. The problem with axiological relativism is that it functions not only on the meta level, but also as an ethical system, proclaiming the

${ }^{1}$ D. Probucka, The Axiological Relativism and the Message of Pope John Paul II, in: D. P. Klimczak, A. Sojka (eds), Literature - Man - Value, Kraków 2007, Instytut Wydawniczy „Maximum”, p. 229-231.

2 Z. Zdunowski, Teaching Philosophy and its Troubles with Truth, "Analiza i Egzystencja" 25 (2014), p. 216-218.

3 J. Majcherek, The Cultural Relativism, Kraków 1995, WSP, p. 154.

${ }^{4}$ I. Lazari-Pawłowska, Ethics, Wrocław 1992, Ossolineum, p. 110. 
thesis of the ontological status of values and norms. Thus, not only views on values change over time and are dependent on place and culture, but the very existence of values such as truth and goodness is not autonomous either. It depends on a specific person and the entire community. A symptom of the crisis of the modern world was recognizing axiological relativism as a model on the level of an ethical system, while rejecting the danger of the fact that this situation leads to axiological indifferentism, i.e. blurring the difference between good and evil, and negating the belief that human actions may be morally better or worse.

Let us consider one more issue. Some philosophers believe that axiological relativism is the inevitable consequence of cultural relativism, which is an empirical fact. In their view, the widespread observability of the latter not only strengthens axiological relativism, but provides a credible reason for its recognition as well. This is one of the tragic errors of modern philosophy. German philosopher Max Scheler talked about this as early as the beginning of the twentieth century. According to him, cultural relativism does not necessarily need to result in axiological relativism, since there is no logically necessary connection between these two theories. The multitude of different cultures and related life ethoses does not result in neither axiological equivalence of these cultures, nor in a postulate to equally accept them. If we accepted this demand as correct, then any behaviour would be allowed. We could then justify racism, nazism, genocide, bestiality, or slavery. The adoption of axiological relativism as a logical consequence of cultural relativism means that all human behaviour is morally equivalent.

Let us go back to the main thread of our considerations associated with the negative consequences of axiological relativisation. Recognition of relativistic thinking as a model leads to the rejection of the hierarchy of the components of human nature, and thus to its degradation. This is because this kind of thinking eliminates the philosophical problem of what is inferior in human nature, and what is on an axiologically higher level. This means de facto abandonment of the process of educational and cultural refining of $\operatorname{man}^{5}$. Thus, the adoption of a relativistic perspective must lead to the belief that all components of human nature are equivalent. Thus, they can be seen as equally important or equally invalid.

${ }^{5}$ A. Kulig-Jęsiek, Ethics - Philosophy - Education in the Light of the Words of John Paul II, "Zeszyty Filozoficzne" (2009) nr 14-15, p. 75-89. 
So what impact would axiological relativism have on the education of the representatives of the species Homo sapiens? At the heart of education lies the assumption that man can advance towards a certain axiological goal, the ideal, which is humanity. After all, education is a continuation of the ancient paideia, based not on who the man is, but who should he become $e^{6}$. How then to shape, to educate a man without ideas of humanity? Relativism takes it in parenthesis, and treats the very requirement for development of the human being as an unauthorised interference with people's right of self-determination. Also, how can a person determine oneself, without knowing that there are higher values, to which one should aspire. Can we search for something when we are not even aware of its existence? How can a man strive for goodness and truth, if he has been raised in the spirit of relativism and has not received the knowledge that good and truth are the most important determinants of humanity? After all, according to relativists, these values are only hypotheses of human mind, components of different narratives, metaphors, and nothing else. What is important in relativism is not what the good and truth are, but what is the utility of these values, since each era, each community, each person has their own truth and their own idea of good.

Accepting this thinking as a model is one of the sources of the crisis of modern schooling, which has lost the deeper meaning of education, reducing it exclusively to passing on knowledge. According to the ancient concept of paideia, school should shape the student's personality, nurture it, and thus, unravel' values for him, and teach their implementation. The current schooling system has long since lost this function, experiencing axiological anomie.

All in all, the dominance of relativistic thinking in contemporary culture means that an individual belief may be considered to be binding. Man becomes the highest authority for himself. He recognizes only his own view as the benchmark of fairness, because he no longer has any other, objective standards. Thus, centuries of collective experience, wisdom accumulated by generations, the tradition, no longer have any meaning ${ }^{7}$.

${ }^{6}$ Z. Kalita, The Philosophy of Paideia. History and the Present, in: D. Probucka, A. Olech, M. Woźniczka (eds), The Passion or Mission? The teaching Philosophy, Częstochowa 2001, WSP, p. 86-93.

7 A. Guggenheim, Pour un nouvel humanism. Essai sur le philosophie de Jean - Paul II, Paris 2011, p. 203. 
Thus understood, relativism leads to permissivism and accepting the view that anything is allowed. Lack of an objective hierarchy of values, or an axiological order causes the decline of the purpose and meaning of life. One's existence begins to resemble roaming without any direction. This direction could have been determined by the ultimate goal, however, it was lost due to the lack of standards and lasting values. What is left are only short-term, ad hoc, temporary goals, characterised by their superficial and episodic character. The meaning of life becomes a quest for a constant change. Due to the lack of a lasting point of reference, lack of axiological foundations, everything that man makes acquires an incidental character, becomes contingent and temporary. Hence, according to Zygmunt Bauman, a human attitude typical of a world dominated by relativistic thinking can be described using four metaphors: ,tourist', ,stroller', ,vagabond', and , gambler ${ }^{8}$.

Although he has a home, the ,tourist' stays there only temporarily because of his constant travels in order to meet other people and cultures, and to experience strong emotions. Therefore, temporality is a fundamental feature of his life. On the other hand, the stroller comes in no deeper contact with people. During episodic meetings, he only engages in small talk with them. His relationships with people have no history, and because of their contingency, will have no future either. Superficiality and episodic character are the hallmarks of his life. On the other hand, the ,vagabond' symbolizes a break with the social order; he stands for ,wild freedom, a freedom with no underlying positive values. The pursuit of constant change becomes more important than finding the leading purpose in life. The last persona, the ,player, symbolises the attitude of a man, who is accompanied by risks and uncertainties all his life. In this case, the risk means the lack of a solid foundation, unchanging principles and values. The surrounding reality is dangerous and the future unpredictable.

At this point, it is difficult to answer the question to what extent axiological relativism is the cause, and to what extent the effect of disintegration of the traditional hierarchy of values and the reason for the spiritual shallowness of human existence. Let us remember that, from a historical perspective, it characterised all periods of decline and was symptomatic of the last stage of civilization. The process of disintegration of the traditional hierarchy of values would be as follows: Moral relativism (adoption of the thesis of the heteronomic

8 Z. Bauman, Two Essays of Postmodern Morality, Warszawa 1994, Instytut Kultury, p. 7-39. 
status of good and evil) - skepticism (ignorance of what is good and bad) - moral nihilism (a belief in the non-existence of good and evil).

In Greek philosophy and Christian philosophy and theology, good and truth were the highest values. These were the basic values upon which the entire European ethics system was built. By stressing the relativity of these values, relativism has initiated the process of their displacement from axiological thinking. The culmination of this process can be considered the philosophy of liberalism, in which good and truth have been replaced by the idea of freedom, recognised as the highest value. Thus, the Christian principle of , doing good and avoiding evil' has been replaced by a directive of ,broadening the scope of one's own freedom. The freedom is understood here as liberation from everything that may be perceived as a restriction. The consequence of this is a contemporary demand of tolerance for what is happening around us. Its negative side are: indifference to injustice, cruelty, deceit, betrayal. This is a tacit consent to lie, involving no judgement and no punishment. This is lack of ideological orientation and axiological indifference. After all, a man who appreciates the truth refuses contact with a liar. In contrast, a man for whom the truth has ceased to be a value, will tolerate a liar, i.e. will show him indulgence, thus forgetting that he had rewarded evil.

\section{The idea of truth in the ethics of Karol Wojtyła - St. John Paul II}

The entire philosophical anthropology of Karol Wojtyła - St. John Paul II could be described as the philosophy of a man who wants to serve the truth. The first book of Karol Wojtyła entitled Ethics Primer, published in 1958, was only the first of a series of work on the same subject. Related topics appear in a later, 1969 book - The Acting Person. However, to these issues he has fully devoted two encyclicals in his pontificate: Veritatis Splendor and Fides et Ratio. According to the Pope, the essence of our humanity is striving towards the truth. This is the only thing that can give a deeper meaning to our existence'. The Pope refers in this case to the metaphysical truth and firmly believes in the possibility of arriving at it. Metaphysical truth would then condition the

9 D. Probucka, The Axiological Relativism and the Message of Pope John Paul II, op. cit. p. 233-235. 
existential truth, understood as a particular way of life based on the identity of thoughts, words and deeds. The Pope is convinced that the third kind of truth - the cognitive (epistemological) truth, understood as a feature of human judgement, is a component of existential truth ${ }^{10}$.

The metaphysical truth is the manifestation of the nature of the world, the ,unveiling of being and understanding it as it is. The Pope assumes that the world may reveal its nature to man. This belief is characteristic of the representatives of the old philosophical mainstream derived from Parmenides, which can be found in the beliefs of Plato, Augustine of Hippo, Thomas Aquinas, and in modern times, developed by the phenomenology of Edmund Husserl and philosophy of Martin Heidegger. It is following the three above-mentioned dimensions of truth and inciting others to such a life that is called by the Pope the diaconate of truth. It is based on man deciding to serve the truth, and confirming this ministry by his words and deeds ${ }^{11}$. This is the essence of the Christian life. St. John Paul II refers in this case to the rules which applied in the early Christian communities. After all, the condition of belonging to the community was a public rejection of the motto diaboli, i.e. renunciation of lies and slander. A Christian was a person who spoke the truth, who has not spoken falsely for himself and others. A Christian was a person who decided to serve the truth, even at the cost of death.

This , ministry of truth' was based on the realisation of the inherent man's need to know oneself, the world and God. It was based on asking questions about the meaning of one's own existence and that of the world. It should also be emphasised that the very effort to reach the truth resulted in the humanisation of those who undertook it. Hence the moral postulate: strive for the truth' was at the same time the principle, according to which our humanity should develop. Thus, seek the truth' would be the same as the directive ,become a human, or ,make your life more human. After all, a human is only the one who knows who he is, who knows himself. These words can be considered as representative for the entire philosophical and theological heritage of St. John Paul II, based on the postulate of searching for the ultimate truth, as well as on realisation of the existential truth, based on the identity of thoughts, words and deeds. For existential truth means a lack of contradiction between a thought and a spoken

10 J. F. Morris, 'Fides et Ratio' and John Paul's Call to Catholic Philosophers: Orthodoxy and/ or the Unity of Truth, in: J. P. Hittinger, The Vocation of the Catholic Philosopher: From Maritain to John Paul II, Washington 2010, p. 196.

11 John Paul II, The Encyclical Fides et Ratio, Poznań 1998, Pallotinum, p. 135. 
opinion, as well as compliance of actions with declarations. The man who is ,in truth' is characterized by the fact that his words are a confirmation of his internal beliefs, and actions do not negate the previously expressed views.

St. John Paul II connects the idea of being in truth with the Christian ethos of life, and opposes it to the civilization based on axiological relativism. In his opinion, such a civilization does not have in itself a sufficient capacity to survive and is doomed to slow decay. In his encyclical Fides et Ratio, the Pope remembers a scene in the Gospel, in which Christ, standing before Pilate, says: ,He who is of the truth will follow me. And Pontius Pilate answers with a question: ,And what is this truth'? Pontius Pilate is a symbol of a civilization that has lost its axiological basis and is therefore doomed to hypocrisy understood as a way of life. Let us also add that the hypocrite is not only the one who lies, but the one who has lost the very ability to distinguish a lie from truth. Hypocrisy would be a kind of social disease, which does not attack human bodies, but destroys the spiritual dimension of culture, negating the objective nature of rules and values.

In the encyclical Fides et Ratio, the Pope indicates two ways to reach the truth, which according to him cannot be separated. This is because they are like two wings on which the human spirit can rise to the contemplate the truth. These are faith (Lat. fides) and reason (Lat. ratio). Hence the need for dialogue between the people of deep faith and the people of rational reflection, as postulated by the Pope. In his opinion, faith is needed in the process of cognition, however, its role should not be to weaken the rigour of thought and to deprive the reason of autonomy. Faith is there to remind people about the transcendental dimension of their existence. Therefore, faith should not limit intellect, but give the cognitive results a deeper, metaphysical sense ${ }^{12}$. In this case, the Pope refers to the ancient Greek word piscis, associating faith with confidence. Thus, to believe is to trust in the cognitive abilities of man, who looks for answers to ultimate questions and wants to reach the absolute truth. On the other hand, the Pope associates reason with the ancient Greek concept of logos orthos, based on nurturing such thinking, which should not only be correct in the logical sense, but also fair and right. Thus, the idea of orthos logos cannot be implemented by an heuristic, who wants to persuade others to their own theses at all cost, and to demonstrate that truth is his. Wojtyła's reason is bona mens - , the good mind'. During one of his visits to Krakow, the Pope recalled the words written on a wall of the house of a medieval chronicler, Jan Dlugosz: There is nothing better than a good mind‘. Therefore,

12 John Paul II, The Encyclical Fides et Ratio, Poznań 1998, Pallotinum, p. 42. 
bona mens means the kind of thinking that serves more than individual interests and particular goals, one which avoids manipulation and cannot be intimidated. It is the mind that implements the ,ministry,' which is the pursuit of truth. The Pope directs this message to each of us, not just to philosophers, theologians or scientists. Therefore, let us cultivate in ourselves a ,good mind,' or such a cognitive power, by means of which we will not manipulate other people and will not agree to being manipulated. This is the mind, which does not want to rule anyone, but it also does not agree to be bound by other people, if the price for it would be the abandonment of truth.

Worth emphasizing is also Wojtyła's postulate of joint thinking and a friendly discussion understood as mutual, friendly criticism focused on solving problems, and not just as a demonstration of the validity of one's position. For when we live and think in isolation, without friends, our reason can become the most important and the only reason. According to the Pope, it is the contemporary cult of individualism that has contributed to the loss of faith in metaphysical truth. Only in dialogue, in interpersonal relations should the ultimate issues be discussed.

Finally, a few words about Wojtyła's concept of person, because what unites the above themes is the idea of man as a free and rational entity, a being capable of doing good and learning the truth. Man is free in the sense that he can decide for himself. However, the activity of his will lies in the fact that he might not want to do what someone else expects of him. To recognise the human right to self-determination is thus to condemn the attempts to interfere in his will, to condemn putting pressure or instrumental treatment. Wojtyła included this postulate in a standard, which he described as ,personalist. This is what it says: , A person cannot be treated as a subject, and in this form, as a means to an end ${ }^{13}$. And is not a lie one of the ways of using another person, or entire societies, in order to pursue one's own, or group interests? Thus, an individual or social consent to a lie and the lack of moral condemnation, which should include refusing to abide with a liar, means a consent to reify a human, to devalue humanity to what is consumable and useful. Therefore, passivity in the face of liars implies indifference to what happens to each of us and to what happens to our culture ${ }^{14}$.

${ }^{13}$ K. Wojtyła, Love and Responsibility, Lublin 1964, KUL, p. 31.

14 John Paul II, The Encyclical Fides et Ratio, p. 72-73. 


\section{Bibilography}

Allsopp M. F., O’Keefe J. J. (eds), Veritatis Splendor. American Responses, Kansas City 1995.

Bauman Z., Two Essays on Postmodern Morality, Warszawa 1994.

Dinoia J. A., Cesario R. (eds), Veritatis Splendor and Renewal of Moral Theology, Chicago 1994.

Guarino T. G., Fides et Ratio: Theology and Contemporary Pluralism, "Theological Studies" (2001) 62, p. 675-700.

Grizes G., 'Veritatis Splendor' Revealed Truth vs. Dissent, "Homiletic and Pastoral Review” (1994) 94, p. 8-17.

Guggenheim A., Pour un nouvel humanism. Essai sur la philosophie de Jean-Paul II, Paris 2011.

Kalita Z., The Philosophy of Paideia. History and the Present, in: D. Probucka, A. Olech, M. Woźniczka (eds), The Passion or Mission? The Teaching Philosophy, Czestochowa 2001, p.17-22.

Kulik- Jęsiek A., Ethics-Philosophy-Education in the Light of the Words of John Paul II, “Zeszyty Filozoficzne" (2009) 14-15, p. 75-89.

John Paul II, The Encyclical Veritatis Splendor, Poznań 1993.

John Paul II, The Encyclical Fides et Ratio, Poznań 1998.

Lazari-Pawłowska I., Ethics, Wrocław 1992.

Majcherek J., The Cultural Relativism, Kraków 1995.

Morris J. F., Fides et Ratio and John Paul's Call to catholic Philosophers: Orthodoxy and/ or the Unity of Truth, in: J. P. Hittinger, The Vocation of the Catholic Philosopher: From Maritain to John Paul II, Washington 2010, p.184-200.

Probucka D., The Axiological Relativism and the Message of Pope John Paul II, in: D. P. Klimczak, A. Sojka (eds), Literature - Man - Value, Kraków 2007, Instytut Wydawniczy "Maximum”, p. 228-236.

Tolhurst J., A Companion to Veritatis Splendor, Leominster 1994.

Wilkins J. (ed.), Understanding Veritatis Splendor, London 1994.

Wilkins J. (ed.), Considering Veritatis Splendor, Cleveland 1994.

Wojtyła K., Love and Responsibility, Lublin 1964.

Wojtyła K., The Sermons 1962-1978, Lublin 1979.

Zdunowski Z., Teaching Philosophy and its Troubles with the Truth, "Analiza i Egzystencja" (2014 ) 25, p. 207-228. 